\title{
Nickel(II) Oxide Solubility and Phase Stability in High Temperature Aqueous Solutions
}

\author{
S.E. Ziemniak, M.A. Goyette
}

\begin{abstract}
This report was prepared as an account of work sponsored by the United States Government. Neither the United States, nor the United States Department of Energy, nor any of their employees, nor any of their contractors, subcontractors, or their employees, makes any warranty, express or implied, or assumes any legal liability or responsibility for the accuracy, completeness or usefulness of any information, apparatus, product or process disclosed, or represents that its use would not infringe privately owned rights.
\end{abstract}


Nickel(II) Oxide Solubility and Phase Stability in High Temperature Aqueous Solutions

S. E. Ziemniak

M.A. Goyette

Lockheed Martin Corporation

P. O. Box 1072

Schenectady, New York 12301-1072 


\begin{abstract}
A platinum-lined, flowing autoclave facility was used to investigate the solubility behavior of nickel(II) oxide $(\mathrm{NiO})$ in deoxygenated ammonium and sodium hydroxide solutions between 21 and $315^{\circ} \mathrm{C}$. Solubilities were found to vary between 0.4 and 400 nanomolal (nm). The measured nickel ion solubilities were interpreted via a $\mathrm{Ni}(\mathrm{II})$ ion hydroxo-and ammino-complexing model and thermodynamic functions for these equilibria were obtained from a least-squares analysis of the data. Two solid phase transformations were observed: at temperatures below $149^{\circ} \mathrm{C}$, the activity of $\mathrm{Ni}(\mathrm{II})$ ions in aqueous solution was controlled by a hydrous Ni(II) oxide (theophrastite) solid phase rather than anhydrous $\mathrm{NiO}$ (bunsenite); above $247^{\circ} \mathrm{C}, \mathrm{Ni}$ (II) activities were controlled by cubic rather than rhombohedral bunsenite.
\end{abstract}

KEYWORDS: Nickel oxide; bunsenite; aqueous solutions, theophrastite; dehydration; hydrothermal solutions; metal ion hydrolysis; pressurized water; corrosion. 


\section{INTRODUCTION}

The degradation of nickel base alloys used to contain hydrothermal solutions in the steam/water circuit of power plants can affect plant longevity and restrict power output. Although material corrosion rates are very low, the steady dissolution, transport and recrystallization of their protective oxide 'skins' may redistribute the corrosion products at selected locations throughout the plant. Such processes are driven by a combination of thermal gradients and alkalinity changes, as explained on the basis of nickel(II) oxide solubility studies conducted in mildly alkaline solutions. ${ }^{(1,2)}$ This work quantified the equilibria for the solid phase transformation reaction

$$
\beta-\mathrm{Ni}(\mathrm{OH})_{2}(s) \rightleftarrows \mathrm{NiO}(s)+\mathrm{H}_{2} \mathrm{O}
$$

(theophrastite) (rhombohedral)

and the sequence of hydrolytic reactions

$$
\mathrm{Ni}^{2+}(a q)+n \mathrm{H}_{2} \mathrm{O} \rightleftarrows \mathrm{Ni}(\mathrm{OH})_{n}^{2-n}(a q)+n \mathrm{H}^{+}(a q)
$$

for $n=1-3$ over the temperature range 25 to $300^{\circ} \mathrm{C}$. In addition, a transformation of rhombohedral to cubic nickel(II) oxide is known to occur around $247^{\circ} \mathrm{C} .{ }^{(3)}$ This transformation is associated with disordering of the aligned magnetic moments of the nickel atoms (i.e., an antiferromagnetic-paramagnetic transformation).

Minimum solubilities of nickel(II) oxide, measured in hydrothermal solutions where the alkalinity was sufficient to stabilize the $\mathrm{Ni}(\mathrm{OH})_{2}(\mathrm{aq})$ hydroxocomplex, were found to be around 2 nanomolal at $300^{\circ} \mathrm{C}^{(1)}$ A measurement uncertainty of $\pm 40 \%$ is associated with these 
measurements, as obtained from triplicate samples using the available analytical instrumentation (atomic absorption). Due in part to these large measurement uncertainties, a number of constraints were applied when thermodynamic properties of the nickel(II) ion hydrolysis products were extracted from the solubility database. As a result, the free energies of formation for $\mathrm{Ni}(\mathrm{OH})^{+}(\mathrm{aq})$ were rather poorly defined and in disagreement with independent free energy estimates of $\mathrm{Ni}(\mathrm{OH})^{+}(\mathrm{aq})$ formation near room temperature. ${ }^{(4)}$

Presently, advances in analytical sensitivity provided by flameless atomic absorption spectroscopy and inductively coupled plasma-mass spectroscopy allow the above uncertainties to be reduced. Therefore, our solubility studies of nickel(II) oxide ${ }^{(2)}$ were extended to lower alkalinities using ammonia and sodium hydroxide at concentrations where the $\mathrm{Ni}(\mathrm{OH})^{+}(\mathrm{aq})$ and $\mathrm{Ni}(\mathrm{OH})_{2}(\mathrm{aq})$ hydroxocomplexes were expected to be stable.

The following report summarizes the results of a six-run test series that investigated the solubility behavior and phase stability of nickel(II) oxide (bunsenite) in aqueous ammonium and sodium hydroxide throughout the temperature range $70-600^{\circ} \mathrm{F}$. The test methodology consisted of pumping various alkaline solutions of known composition through a bed of granular $\mathrm{NiO}$ and analyzing the emergent solutions for nickel. All test solutions were maintained oxygen-free by sparging with nitrogen. Equilibria for the following chemical reactions were described in thermodynamic terms: (a) $\beta-\mathrm{Ni}(\mathrm{OH})_{2}$ (theophrastite) or $\mathrm{NiO}$ (bunsenite) dissolution, (b) $\mathrm{Ni}(\mathrm{II})$ ion hydroxocomplex formation (hydrolysis) and (c) Ni(II) ion amminocomplex formation. 


\section{EXPERIMENTAL}

\section{Materials}

To minimize generation of fine particulate material, which would interfere with the solubility measurements, a coarse, granular form of nickel oxide was prepared using certified nickel(ous) oxide, green, supplied by the Fisher Scientific Company (lot \# 782699). The as-received powder was first compacted under 38,000 psi pressure and attrited through a \#8 mesh sieve $(2.362 \mathrm{~mm})$ onto a $\# 20$ mesh sieve $(0.85 \mathrm{~mm})$. The coarsened particles were then fired at $1200^{\circ} \mathrm{C}$ for 15 hours in an air furnace and quenched into liquid nitrogen. These sintering conditions proved to be insufficient, as many fines were observed during subsequent exposure to water washing. A second firing at $1450^{\circ} \mathrm{C}$ for four hours, followed by quenching in liquid nitrogen, produced sufficiently dense particles that did not generate fines upon exposure to water.

The material produced in the above manner consisted of hard, irregular-shaped, olive-green particles with dimensions $0.85-2.4 \mathrm{~mm}$. Density determinations using a mercury pycnometer gave a value of $5.447 \mathrm{~g} \mathrm{~cm}^{-3}$ ( $80 \%$ of theoretical). Powder X-ray diffraction analyses, performed using copper $\mathrm{K}_{\alpha}$ radiation, confirmed the absence of impurity phases.

Two polymorphs of nickel(II) oxide are known: rhombohedral and cubic (bunsenite), i.e., PDF Nos. 44-1159 and 47-1049, respectively. ${ }^{(5)}$ Although all of the lower angle diffractions were consistent with cubic $\mathrm{NiO}$, examination of the higher angle peaks $\left(2 \theta>100^{\circ}\right)$ revealed peak splitting characteristic of a rhombohedral phase, see Fig. 1. The calculated lattice parameters were $a=2.9552(1)$ and $c=7.2275(3) \AA$. These values are in exact agreement with those in the PDF database. ${ }^{(5)}$ 
Deionized, deoxygenated water (obtained from charcoal and mixed-bed ion exchange resin columns) was used throughout the experimental program. This water had a resistivity $>1 \mathrm{Mohm}$ $\mathrm{cm}$ and contained $<0.1 \mathrm{mg} / \mathrm{L}$ silica. Trace contaminant levels of iron $(2 \mathrm{~nm})$ and nickel (3-6 nm) were present in the water during the first phase of solubility testing $\left(\leq 149^{\circ} \mathrm{C}\right)$, which were reduced to $<0.8 \mathrm{~nm}$ during the final test phase. Commercial-grade nitrogen gas was used to sparge dissolved oxygen to values $<0.005 \mathrm{mg} / \mathrm{L}$. Test solutions were prepared volumetrically in the feed tanks using ultrapure ammonium hydroxide, or in some cases, reagent grade sodium hydroxide.

\section{$\underline{\text { Apparatus }}$}

The solubility measurements were made using the flowing autoclave arrangement shown in Fig:

2. The feed tanks, pump, filter holder and tubing between the feed tanks and first autoclave were stainless steel. The two test autoclaves were stainless steel with platinum liners. The tubing, cooler and valves (which comprised the sampling station) were stainless steel, the tubing and cooler having platinum linings. The feed tanks, each having a 115 liter capacity, were filled with deoxygenated, deionized water. Midway through the test program the feed tanks were teflonlined and equipped with supplemental ion exchange capability to reduce contaminant input levels of nickel to $<0.8 \mathrm{~nm}$. Additions of solutions containing reagent grade chemicals were made to obtain the desired feedwater compositions. These compositions are listed in Table I.

Nitrogen gas was bubbled through the feed solution and one atmosphere of this gas was maintained over the feed solution during all tests. The nitrogen concentration in the feedwater was calculated to be $1115 \mu \mathrm{mol} / \mathrm{kg}$ based on pressure in the feed tank and Henry's law coefficient for the solubility of nitrogen in water. ${ }^{(6)}$ 
A Milton Roy piston-type pump supplied feedwater to the high-pressure system. A flow rate of $6.0 \pm .5 \mathrm{cc} / \mathrm{min}$ (at room temperature) was maintained. From the pump, the feedwater passed through a high-pressure filter holder containing a $0.2 \mu \mathrm{m}$ Uni-Pore ${ }^{\mathrm{TM}}$ polycarbonate filter membrane. After the filter, the feed solution entered two platinum-lined autoclaves connected in series. Each autoclave had an internal volume of $\sim 100 \mathrm{~cm}^{3}$. The first autoclave was empty and acted as a solution preheater, whereas the second autoclave contained 329 grams of nickel(II) oxide. Platinum screens, located at the inlet and outlet of the second autoclave, were used to confine particulate material to the autoclave. The average contact time between the feed solution and the bed was 4.6 to 6.7 minutes, depending on the temperature.

After leaving the second autoclave, the test solution flowed immediately through a stainless steel cross, one leg of which was dead-ended and contained a platinum-sheathed thermocouple to monitor temperature of the exiting solution. The main leg directed flow into the sampling line, while the remaining leg provided a secondary path through which flow could be diverted in case the sampling line became plugged. This leg was also connected to a pressure gauge which monitored system pressure.

The sampling system consisted of a water-jacketed cooler and a pressure-regulating valve, located immediately upstream of the sample collection point. For safety purposes, a second valve (which always remained open) was installed between the cooler and pressure-regulating valve. All tubing between the two autoclaves and between the outlet of the second autoclave and sample collection point, including the cooler, were high-pressure Alloy 600 tubing lined with 
platinum. Both valves in the sampling system were stainless steel and had titanium internals. During normal operation, the system pressure was maintained in the range 13.1-14.1 MPa.

Heat was supplied to the autoclaves by a Chromalox electrical heating element jacket, the temperature being controlled by a Modicon PD programmable logic controller (PLC). System temperatures were monitored with iron-constantan (J Type) thermocouples at three locations: (1) outer surfaces of the first and second autoclaves ( 4 in parallel per autoclave, read as an average), (2) tubing at entrance and outlet of the second autoclave (2), and (3) in the flow stream at the second autoclave outlet. The thermocouples had been purchased with a stated 'special error limit' of $\pm 1.1^{\circ} \mathrm{C}$; their outputs were also displayed on the PLC.

\section{Operational and Analytical Procedures}

In anticipation of a solid-phase transformation reaction, demonstrated to occur in previous solubility testing of nickel(I) oxide, ${ }^{(2)}$ the test program was conducted in two stages: a low temperature portion $\left(21-149^{\circ} \mathrm{C}\right)$, followed by a high temperature portion $\left(149-315^{\circ} \mathrm{C}\right)$. All low temperature runs were completed prior to the high temperature runs to eliminate system hysteresis effects due to sluggish hydration/dehydration effects.

Prior to the start of each test run, one of the feed tanks was prepared by rinsing, flushing and filling with demineralized water. After chemical addition, the tank was sparged with nitrogen gas to facilitate mixing and to minimize oxygen. A one-atmosphere blanket of nitrogen gas was placed over the feed water upon completion of the sparging operation. The NiO bed was then flushed for a minimum of three days, using a system flow rate of $\operatorname{six~} \mathrm{ml} \mathrm{min}^{-1}$. The flushing period insured adequate time for equilibration with each test chemistry. The sampling sequence, 
during which six samples were collected in autosampler vials, was then initiated. After sampling, the PLC was set to establish a new temperature. Although 120 to 150 minutes were required to establish the new temperature, the system was allowed to stabilize at the new temperature for at least one day before the sampling procedure was repeated.

In a similar manner, each high temperature sequence was initiated after system operation at $260^{\circ} \mathrm{C}$ for at least 3 days. The sampling sequence was conducted in an increasing/decreasing/ increasing mode so that the 163 to $316^{\circ} \mathrm{C}$ interval was conducted in increasing increments of $14^{\circ} \mathrm{C}$.

Feed tank and system effluent samples were collected during each run and analyzed for $\mathrm{pH}$, conductivity and oxygen. Ammonia was determined by ion chromatography, while sodium hydroxide was determined by acid-base titration using standardized hydrochloric acid solutions.

\section{GFAA}

All liquid samples collected during the low temperature test stage were analyzed for nickel by flameless atomic absorption techniques. A Perkin-Elmer Model 5000 Zeeman Atomic Absorption Spectrophotometer, equipped with a graphite furnace, was used. A set of standard solutions ( $0.1 \underline{\mathrm{N}}$ nitric acid containing known amounts of nickel) was analyzed with each group of samples. The normal analytical procedure was to collect approximately a $2 \mathrm{~mL}$ sample aliquot in an acid-leached, polystyrene autosampler vial to which $25 \mu \mathrm{L}$ of concentrated, high purity nitric acid had been added. Samples containing $<17 \mathrm{~nm}$ Ni were pre-concentrated using multiple delivery and drying steps prior to performing the atomization step. Analytical accuracy is expected to decrease with concentration: $\pm 10 \%$ for $\geq 17 \mathrm{~nm}$ to $\pm 30 \%$ at $3 \mathrm{~nm}$. 


\section{ICPMS}

Due to the lower nickel solubilities encountered during some of the high temperature runs, larger volume samples $(\sim 30 \mathrm{ml})$ were collected in acid-leached Nalgene bottles. The samples were acidified to $0.5 \%$ or $1.0 \%$ nitric acid at least one day prior to analysis. Additional samples were obtained from the teflon-lined feed tanks to determine background levels of nickel in the feedwater. An HP4500 Series 300 Inductively Coupled Plasma Mass Spectrometer manufactured by Hewlett-Packard was used for these analyses. Analytical accuracy is expected to be better than $\pm 20 \%$ above $0.2 \mathrm{~nm}$.

\section{$\underline{\text { RESULTS }}$}

Solubility

Results from the experimental program, in terms of measured nickel solubilities as a function of temperature, are presented in Tables II and III. The elemental nickel concentrations represent averages of six samples and are given in units of nanomolal (nm, nanomoles of nickel per kilogram of solution). The small amounts of material lost in the sampling line have been neglected. The temperature value listed for a particular sample was the downstream thermocouple reading after sampling was completed. Total measured nickel solubilities ranged between 0.4 and $400 \mathrm{~nm}$.

\section{Thermodynamic Analysis}

Given the hydrothermal environments in which nickel(II) oxide was exposed, two dissolution reactions and two sequences of $\mathrm{Ni}(\mathrm{II})$ hydrolysis and amminocomplexing reactions are possible: 
or

$$
\beta-\mathrm{Ni}(\mathrm{OH})_{2}(\mathrm{~s})+2 \mathrm{H}^{+}(\mathrm{aq})=\mathrm{Ni}^{2+}(\mathrm{aq})+2 \mathrm{H}_{2} \mathrm{O}
$$

and

$$
\mathrm{NiO}(\mathrm{s})+2 \mathrm{H}^{+}(\mathrm{aq})=\mathrm{Ni}^{2+}(\mathrm{aq})+\mathrm{H}_{2} \mathrm{O}
$$

$$
\begin{aligned}
& \mathrm{Ni}^{2+}(a q)+n \mathrm{H}_{2} \mathrm{O} \rightleftarrows \mathrm{Ni}(\mathrm{OH})_{n}^{2-n}(a q)+n H^{+}(a q) \\
& \mathrm{Ni}(\mathrm{OH})_{\mathrm{n}}{ }^{2-n}(\mathrm{aq})+\mathrm{NH}_{3}(\mathrm{aq})=\mathrm{Ni}(\mathrm{OH})_{\mathrm{n}}\left(\mathrm{NH}_{3}\right)^{2-\mathrm{n}}(\mathrm{aq})
\end{aligned}
$$

where $\mathrm{n}=0,1,2$ and 3 .

By expressing the concentration of each possible $\mathrm{Ni}(\mathrm{II})$ ion complex in terms of an equilibrium constant and calculable $\mathrm{H}^{+}$ion and undissociated $\mathrm{NH}_{3}$ concentrations, the measured $\mathrm{Ni}$ (II) ion solubilities were separated into contributions from each of the individual complexes. The total molality of nickel in solution (i.e., saturation solubility limit) was then calculable by summation over all mononuclear Ni(II) ion species present. The thermodynamic relationships

$$
-R T \ln K=\Delta G=\Delta H-T \Delta S
$$

were introduced at this point to permit calculation of all $\mathrm{Ni}(\mathrm{II})$ ion complex concentrations as functions of temperature. Where necessary, a three-parameter model was used to describe $\Delta \mathrm{G}(\mathrm{T})$. This approximation assumes that the difference in heat capacities between reactants and products for each reaction is a constant (C). Integration of the applicable thermodynamic relationship gives

$$
\Delta G(T)=A-B T-C T \ln T
$$

where the constants $A, B$ and $C$ have the thermodynamic significance: $A=\Delta H(298)-298 \Delta C_{p} ; B$ $=\Delta S(298)-(1+\ln 298) \Delta C_{p}$; and $C=\Delta C_{p}$. Normally, inclusion of the heat capacity term in Eq. (7) is unwarranted. It is, in fact, possible to minimize curvature in hydrolytic $\Delta G(T)$ correlations by rewriting the reaction, using $\mathrm{H}^{+}$or $\mathrm{OH}^{-}$ions as needed, to balance like charges on the reactant side with those on the product side. By this 'isocoulombic' principle, ${ }^{(7)}$ it is seen that only the $\mathrm{n}=$ 
3 form of Eq. (2) is not in the form which minimizes heat capacity effects. Therefore, a heat capacity effect on the order of $-225 \mathrm{~J} / \mathrm{mol}-\mathrm{K}$ is expected for the Eq. (2) equilibrium which creates the $\mathrm{Ni}(\mathrm{OH})_{3}{ }^{-}$species.

Evaluation of the experimental solubilities of Tables II and III in terms of concentrations of the possible hydrolyzed/complexed $\mathrm{Ni}$ (II) species present required that the $\mathrm{pH}$ (hydronium ion concentration) be known at the existing solution conditions. This quantity depended on the molality of the alkaline reagents dissolved in solution (i.e., ammonia or sodium hydroxide), as well as their ionization constants and that of $\mathrm{H}_{2} \mathrm{O}$. The latter parameters, which are functions of solution temperature, are defined below in terms of thermodynamic activities ( ) and tabulated in Table IV.

$$
\begin{gathered}
K_{w}=\left(H^{+}\right)\left(O H^{-}\right) \\
K_{B}=\left(N H_{4}^{+}\right)\left(O H^{-}\right) /\left(N H_{3}\right) \\
\text { with } \quad \log K=b_{1} / T+b_{2}+b_{3} \ln T+b_{4} T+b_{5} / T^{2}
\end{gathered}
$$

Both $\mathrm{K}_{\mathrm{w}}$ and $\mathrm{K}_{\mathrm{B}}$ were pressure-corrected (to $13.1 \mathrm{MPa}$ ), as well as ionic strength-corrected, using the correlations. ${ }^{(8,9)}$

Equilibrium constants for Eqs. (2) - (5) were corrected for small deviations from ideal solution behavior by distinguishing between ionic concentration (i.e., molality) and thermodynamic activity

$$
\left(a_{i}\right)=\gamma_{i}\left[C_{i}\right]
$$


where $\left(a_{i}\right)$ is the thermodynamic activity, $\gamma_{i}$ the ionic activity coefficient and $\left[C_{i}\right]$ is the ionic concentration. Generally, it was assumed that ionic activity was related to ionic strength by an extended Debye-Hückel expression ${ }^{(10)}$

$$
\log \gamma_{i}=-S Z_{i}^{2} \sqrt{ } I /(1+1.5 \sqrt{ } I)
$$

where $S$ is the temperature-dependent, ${ }^{(11)}$ limiting Debye-Hückel slope $(0.51$ at $298 \mathrm{~K}), Z_{\mathrm{i}}$ is the ionic charge number, and $I$ is the ionic strength $\left(=(1 / 2) \Sigma C_{i} Z_{i}^{2}\right)$.

An overall ion electroneutrality balance was finally applied to determine $\left[\mathrm{H}^{+}\right]$for each data point. In ammonium hydroxide solutions, the balance is:

$$
\begin{gathered}
\sum_{n=0}^{3}(2-n)\left[\mathrm{Ni}(\mathrm{OH})_{n}^{(2-n)+}\right]+\sum_{m=0}^{3}(2-m)\left[\mathrm{Ni}(\mathrm{OH})_{m}\left(\mathrm{NH}_{3}\right)^{(2-m)+}\right] \\
+\left[\mathrm{NH}_{4}^{+}\right]+\left[\mathrm{H}^{+}\right]=\left[\mathrm{OH}^{-}\right]
\end{gathered}
$$

The relatively low ammonia concentrations, together with existing information on multiple ammonia complexing equilibria, ${ }^{(12)}$ indicate that multiple ammonia complex concentrations are expected to be low and have a negligible impact on $\mathrm{pH}$. Hence the added complexity introduced by their inclusion in the neutrality balance is not justified.

Since all terms were expressible in terms of temperature and total dissolved ammonia concentrations, Eq. (13) was reduced to an algebraic equation in terms of the remaining unknown, $\left[\mathrm{H}^{+}\right]$. To determine how a given scheme of $\mathrm{Ni}(\mathrm{II})$ complexes in solution could fit the results, a set of thermodynamic constants was substituted into the neutrality balance, and $\left[\mathrm{H}^{+}\right]$ concentrations were calculated by a Newton-Raphson iteration procedure. These $\left[\mathrm{H}^{+}\right]$values 
were then used to compute all the soluble nickel species which, after being summed, could be compared with the measured $\mathrm{Ni}$ solubilities. The differences were then minimized via a generalized, non-linear, least-squares curve-fitting routine based on Marquardt's algorithm. ${ }^{(13)}$

When the solubility data were analyzed, the importance of relative errors (i.e., percentage errors), rather than absolute errors, was accounted for by minimizing differences between the logarithms of the experimental and the predicted solubilities. The thermodynamic functions obtained were then resubstituted into the neutrality balance, and the two step process was repeated.

Convergence, i.e., the condition when the calculated thermodynamic functions ceased to change, was attained in a few cycles because the dissolved metal ion concentrations were very low and had only a minor influence on changes in solution $\mathrm{pH}$.

The effects of two solid phase transformations were accounted for by: (1) assuming the presence of a $\mathrm{Ni}(\mathrm{OH})_{2} / \mathrm{NiO}$ phase boundary at $155^{\circ} \mathrm{C}$, fitting thermodynamic properties for both solids, and then recalculating the phase boundary provided by the least-squared analysis, and (2) allowing for the rhombohedral to cubic transformation of NiO based on the existence of a heat capacity anomaly above $247^{\circ} \mathrm{C} .{ }^{(3)}$ That is, the Eq. (7) fit of the Eq. (4) dissolution reaction was allowed to take on a different slope above $247^{\circ} \mathrm{C}$.

Results of the above data fitting procedure are shown in Figs. 3 - 5. The following previously unreported nickel(II) oxide solubility results, obtained during testing in our laboratory in 1982, ${ }^{(2)}$ are included in Fig. 3 with data from Runs 1 and 1A/1B:

Feed Chemistry: $0.075 \pm 0.029 \mathrm{~mm} \mathrm{NH}$ 
$\mathrm{pH} @ 25^{\circ} \mathrm{C}=9.39 \pm 0.04$

\section{$\underline{N i, n m}$}

112.

245.

271.

347.
Temp, $\mathrm{K}$

296.5

326.5

342.6

355.4 conductivity $=7.44 \pm 0.19 \mu \mathrm{S} / \mathrm{cm}$

Ni,nm Temp, K

409.

367.0

376.

382.6

453.

394.8

419.

408.2

In these plots the two dissolution reaction equilibria, i.e., Eqs. $(3,4)$, as well as the ammonia complexing equilibria, and all but one of the Ni(II) ion hydrolytic equilibria were fitted using Eq. (7) with $\mathrm{C}=0$. As discussed above, $\Delta \mathrm{C}_{\mathrm{p}}{ }^{\circ}$ for the third stepwise hydrolysis reaction, Eq. (2), was fixed as that for water ionization $(-223.79 \mathrm{~J} / \mathrm{mol}-\mathrm{K})^{(11)}$, in recognition of the isocoulombic principle. In addition to the unhydrolyzed $\mathrm{Ni}^{2+}(\mathrm{aq})$ ion, statistically significant fits were obtained for the thermodynamic functions for four other hydrolytic products: $\mathrm{Ni}(\mathrm{OH})^{+}, \mathrm{Ni}(\mathrm{OH})_{2}(\mathrm{aq})$, $\mathrm{Ni}(\mathrm{OH})\left(\mathrm{NH}_{3}\right)^{+}$and $\mathrm{Ni}(\mathrm{OH})_{2}\left(\mathrm{NH}_{3}\right)(\mathrm{aq})$.

Table $\mathrm{V}$ presents the fitted thermochemical parameters for the Ni(II) oxide dissolution reactions and the applicable hydrolysis and complexing reactions. These fits resulted in an overall standard deviation between measured and fitted nickel solubilities of $\pm 25 \%$ for a database consisting of 147 entries. This level of uncertainty is consistent with the improved analytical sensitivities available at sub-nanomolal concentrations.

\section{DISCUSSION OF RESULTS}

A. Extraction of Thermodynamic Properties for $\mathrm{Ni}^{2+}(\mathrm{aq})$ 
The present $\mathrm{Ni}(\mathrm{II})$ ion solubility database was interpreted by recognizing equilibria for the dissolution of three solid-phases: hydrous nickel(II) oxide (theophrastite), rhombohedral nickel(II) oxide and cubic nickel(II) oxide. The standard free energy changes fitted for the first two reactions: $-67.45 \pm 0.47 \mathrm{~kJ} \mathrm{~mol}^{-1}$ and $-70.18 \pm 0.98 \mathrm{~kJ} \mathrm{~mol}^{-1}$, respectively (see Table V), agree well with independent literature results. For example, recent solubility measurements of theophrastite at room temperature ${ }^{(15)}$ give $\Delta \mathrm{G}^{\circ}(298)=-67.91 \pm 0.59 \mathrm{~kJ} \mathrm{~mol}^{-1}$ for Eq. (3), while refined thermodynamic properties for $\mathrm{Ni}^{2+}(\mathrm{aq}),{ }^{(14)}$ bunsenite ${ }^{(3)}$ and water ${ }^{(12)}$ give $\Delta \mathrm{G}^{\circ}(298)=$ $-69.94 \mathrm{~kJ} \mathrm{~mol}^{-1}$ for Eq. (4).

Temperature dependencies for the Eqs. $(3,4)$ equilibria are plotted in Fig. 6. A 'literature' estimate for the theophrastite dissolution equilibrium, Eq. (3), was obtained by employing a $\Delta \mathrm{H}_{\mathrm{f}}{ }^{\circ}(298)$ value for $\beta-\mathrm{Ni}(\mathrm{OH})_{2}$ extracted from a Fisher-Zen analysis ${ }^{(17)}$ of data for the $\beta$ $\mathrm{Ni}(\mathrm{OH})_{2} / \mathrm{NiO}$ transformation. The latter analysis gave $\Delta \mathrm{H}_{\mathrm{f}}{ }^{\circ}$ (theophrastite $)=\Delta \mathrm{H}_{\mathrm{f}}{ }^{\circ}$ (bunsenite) $291.83 \mathrm{~kJ} \mathrm{~mol}^{-1}{ }^{(18)]}$ This result provides

$$
\Delta \mathrm{G}^{\circ}(\mathrm{T}), \mathrm{J} \mathrm{mol}^{-1}=-94130+87.94 \mathrm{~T}
$$

for Eq. (3). Independently-estimated free energy changes for the bunsenite dissolution reaction, Eq. (4), based on available $\Delta \mathrm{G}_{\mathrm{f}}{ }^{\circ}(298), \mathrm{S}^{\circ}(298)$ and $\mathrm{C}_{\mathrm{p}}{ }^{\circ}(298)$ values for $\mathrm{NiO}^{(3)}, \mathrm{Ni}^{2+}(\mathrm{aq})^{(14,16)}$ and water ${ }^{(12)}$ give

$$
\Delta \mathrm{G}^{\circ}(\mathrm{T}), \mathrm{J} \mathrm{mol}^{-1}=-96302+15.26 \mathrm{~T}+12.84 \mathrm{~T} \ln \mathrm{T}
$$

Eq. (15) is expected to become less accurate above $520 \mathrm{~K}$ due to its inability to account for the heat capacity anomaly associated with the transformation of rhombohedral to cubic $\mathrm{NiO}$.

Despite this shortcoming, Eqs. $(14,15)$ are seen to agree with the present experimental results to within $3 \mathrm{~kJ} \mathrm{~mol}^{-1}$ over the temperature range of the study, see Fig. 6. 
It is of interest to note that the $\Delta G^{\circ}(T)$ correlation for Eq. (4) based on previous solubility measurements ${ }^{(1)}$ deviate from the literature predictions by more than $6 \mathrm{~kJ} \mathrm{~mol}^{-1}$ at the upper temperature limit due to a greater sensitivity to temperature changes (see Fig. 6). This behavior is believed to be an artifact caused by too large a $\Delta \mathrm{C}_{\mathrm{p}}{ }^{\circ}$ value for Eq. (4), i.e., $-77.9^{(1)}$ vs. $-12.8 \mathrm{~J}$ $\mathrm{mol}^{-1} \mathrm{~K}^{-1}$

A refined set of thermodynamic properties for $\mathrm{Ni}^{2+}(\mathrm{aq})$ may be extracted from the fitted equilibrium for the rhombohedral $\mathrm{NiO}$ dissolution reaction given in Table $\mathrm{V}$ by assuming that most of the discrepancy between prediction and measurement lies in the assumed properties for $\mathrm{Ni}^{2+}(\mathrm{aq})$, whose stated uncertainty is $\pm 2 \mathrm{~kJ} \mathrm{~mol}^{-1}{ }^{(4)}$ Therefore, combining the more precise solubility-based equilibrium for Eq. (4) with the properties of $\mathrm{NiO}$ and $\mathrm{H}_{2} \mathrm{O}$ gives $\Delta \mathrm{G}_{\mathrm{f}}^{\circ}(298)=$ $43.7 \mathrm{~kJ} \mathrm{~mol}^{-1}, \Delta \mathrm{H}_{\mathrm{f}}^{\circ}(298)=51.2 \mathrm{~kJ} \mathrm{~mol}^{-1}$ and $\mathrm{S}^{\circ}(298)=126.0 \mathrm{~J} \mathrm{~mol}^{-1} \mathrm{~K}^{-1}$ for $\mathrm{Ni}^{2+}(\mathrm{aq})$.

In a similar manner, a refined set of thermodynamic properties for $\beta-\mathrm{Ni}(\mathrm{OH})_{2}$ may be extracted from the fitted equilibrium for the theophrastite dissolution reaction (Table V) using the aboverefined properties for $\mathrm{Ni}^{2+}(\mathrm{aq}): \Delta \mathrm{G}_{\mathrm{f}}^{\circ}(298)=-450.5 \mathrm{~kJ} \mathrm{~mol}^{-1}, \Delta \mathrm{H}_{\mathrm{f}}^{\circ}(298)=-533.0 \mathrm{~kJ} \mathrm{~mol}^{-1}$ and $S^{\circ}(298)=89.1 \mathrm{~J} \mathrm{~mol}^{-1} \mathrm{~K}^{-1}$.

\section{B. Nickel(II) Oxide Solid Phase Transformations}

Estimation of the dehydration temperature for Eq. (1), based on equality of the fitted free energy changes for Eqs. (3) and (4) provided in Table V, yields a threshold temperature of $149^{\circ} \mathrm{C}$. An independent estimate, derived from literature-based predictions of the equilibria for Eqs. $(3,4)$ in the previous section, i.e., Eqs. $(14,15)$, is calculated to be $154^{\circ} \mathrm{C}$. The good agreement between 
measurement and prediction is further supported by recent observations regarding the stable oxide layer formed on corroding nickel surfaces exposed in non-deaerated, hydrothermal systems: a transformation from $\beta-\mathrm{Ni}(\mathrm{OH})_{2}$ to $\mathrm{NiO}$ occurred around $160^{\circ} \mathrm{C} .{ }^{(19)}$ Therefore, the results from our previous nickel(II) oxide solubility study, which indicated a transformation at $195^{\circ} \mathrm{C},{ }^{(2)}$ were probably biased by sluggish dehydration kinetics.

The transformation from rhombohedral to cubic nickel(II) oxide

$$
\mathrm{NiO}(s, \text { rhombohedral }) \rightleftarrows \mathrm{NiO}(s, \mathrm{cubic})
$$

is characterized by a decrease in heat capacity at $247^{\circ} \mathrm{C}$, which continues until $434^{\circ} \mathrm{C}$, when a minimum is reached and further temperature increases lead to increases in heat capacity. ${ }^{(3)}$ The impact of this thermal anomaly on the calculated free energy changes for the nickel oxide dissolution reaction was modeled by recognizing that a different $\Delta S^{\circ}$ value would be required above $247^{\circ} \mathrm{C}$. Since entropy is a heat capacity integral, it follows that cubic NiO has a lower entropy than rhombohedral NiO. Therefore, a higher value of $\Delta S^{\circ}$ for the Eq. (4) dissolution reaction is expected at temperatures above $247^{\circ} \mathrm{C}$. The fitted $\Delta \mathrm{S}^{\circ}$ value (see Table V) is $-64.76 \pm$ $10.50 \mathrm{~J} \mathrm{~mol}^{-1} \mathrm{~K}^{-1}$, an increase of $30.5 \mathrm{~J} \mathrm{~mol}^{-1} \mathrm{~K}^{-1}$ relative to that fitted for the dissolution of rhombohedral NiO. Allowing for the limitations of Eq. (7), the qualitative agreement between fit and expectation is considered adequate.

\section{Nickel(II) Ion Hydrolysis}

Free energy changes for the first two hydrolysis reactions are plotted in Fig. 7. The standard free energy change for the first hydrolysis reaction was found to be $53.94 \pm 0.65 \mathrm{~kJ} \mathrm{~mol}^{-1}$. This result compares favorably with a literature value of $55.14 \pm 0.17 \mathrm{~kJ} \mathrm{~mol}^{-1(4,12)}$ and represents an 
improvement over the result obtained from a previous high temperature solubility study of $\mathrm{NiO}$, $68.6 \pm 9.4 \mathrm{~kJ} \mathrm{~mol}^{-1}{ }^{(1)}$ which was considered inconclusive.

The present results are believed to be the first reliable determination of the equilibrium for the $n$ $=1$ form of Eq. (2) at high temperatures. Agreement with the Refs. $(4,12)$ results is considered to be excellent, given the limited temperature range $\left(15-42^{\circ} \mathrm{C}\right)$ of the previous study. On the other hand, the previous Ref. 1 results straddle the present results by $\pm 7 \mathrm{~kJ} \mathrm{~mol}^{-1}$ at temperatures between 125 and $275^{\circ} \mathrm{C}$. The larger deviations at temperatures above $260^{\circ} \mathrm{C}$ appear to be a compensation for the inappropriate $\Delta \mathrm{C}_{\mathrm{p}}{ }^{\circ}$ value used by Ref. 1 to fit free energy changes for the bunsenite dissolution reaction, Eq. (4).

Gibbs energy changes fitted to the two step hydrolysis reaction

$$
\mathrm{Ni}^{2+}(\mathrm{aq})+2 \mathrm{H}_{2} \mathrm{O} \rightleftharpoons \mathrm{Ni}(\mathrm{OH})_{2}(\mathrm{aq})+2 \mathrm{H}^{+}(\mathrm{aq})
$$

per Table V are also plotted in Fig. 7. The standard Gibbs energy change for Eq. (17) is 129.63 $\pm 3.16 \mathrm{~kJ} \mathrm{~mol}^{-1}$. The higher uncertainty in $\Delta \mathrm{G}^{\circ}(298)$ for Eq. (17) is caused by extrapolation of very low fitted concentrations of the $\mathrm{Ni}(\mathrm{OH})_{2}(\mathrm{aq})$ species, having a normal sensitivity to temperature changes, to room temperature. For example, the expected concentration of $\mathrm{Ni}(\mathrm{OH})_{2}$ (aq) resulting from theophrastite dissolution at $25^{\circ} \mathrm{C}$ is 0.01 nanomolal. Concentrations of the $\mathrm{Ni}(\mathrm{OH})^{+}(\mathrm{aq})$ and $\mathrm{Ni}(\mathrm{OH})_{2}(\mathrm{aq})$ species in Run 5 do not become equivalent (i.e., 0.17 nanomolal) until the temperature reaches $185^{\circ} \mathrm{C}$.

It is noted that free energy changes for Eq. (17) were determined previously ${ }^{(1,2)}$ by subtracting free energy changes for Eq. (4) from those determined for 


$$
\mathrm{NiO}(\mathrm{s})+\mathrm{H}_{2} \mathrm{O}=\mathrm{Ni}(\mathrm{OH})_{2}(\mathrm{aq})
$$

Due to the apparent bias in the Ref. 1 fit for Eq. (4) and the lack of appropriate data in Ref. 2 to determine $\Delta G^{\circ}(T)$ for Eq. (4), the Table V parameters for Eq. (4) were combined with the results of Refs. 1 and 2 for Eq. (18) to provide a mutually-consistent basis upon which to compare $\Delta G^{\circ}(T)$ estimates for the two step hydrolysis reaction. Fig. 7 shows that the revised $\Delta G^{\circ}(T)$ estimates of Ref. 2 are about 5-6 kJ mol-1 lower than those of the revised Ref. 1 estimates. This difference is probably caused by underestimation of phosphatocomplexing in the Ref. 2 study.

However, the present results are more than $7 \mathrm{~kJ} \mathrm{~mol}^{-1}$ greater than the revised Ref. 1 estimates. This difference is indicative of the significantly lower minimum Ni(II) ion solubilities measured at elevated temperatures: 0.5 nanomolal (Runs 5, 6) versus 3 nanomolal (Ref. 1) at $260^{\circ} \mathrm{C}$.

Previous NiO solubility measurements at elevated temperatures had reported that the $\mathrm{Ni}(\mathrm{II})$ ion third stepwise hydrolysis reaction

$$
\mathrm{Ni}(\mathrm{OH})_{2}(\mathrm{aq})+\mathrm{H}_{2} \mathrm{O}=\mathrm{Ni}(\mathrm{OH})_{3}(\mathrm{aq})+\mathrm{H}^{+}(\mathrm{aq})
$$

occurred when sodium hydroxide concentrations exceeded 3 millimolal, i.e., $\mathrm{pH}\left(\right.$ at $\left.25^{\circ} \mathrm{C}\right)>11.4$.

$(1,2)$ In these solutions bunsenite solubilities increased with sodium hydroxide concentration as well as temperature. Although Runs 5 and 6 indicated that bunsenite solubilities had indeed reached minimum levels with respect to alkalinity changes, and had begun to increase with temperature, solubility increases with respect to alkalinity increases were not observed, compare Figs. 4 and 5. Such behavior indicates that $\mathrm{Ni}(\mathrm{OH})_{2}(\mathrm{aq})$, rather than $\mathrm{Ni}(\mathrm{OH})_{3}{ }^{-}(\mathrm{aq})$, was controlling $\mathrm{NiO}$ solubility. 
Attempts to include the Eq. (19) equilibrium in regression analyses of the present database were unsuccessful, as they resulted in no significant reduction in least-squares residuals.

\section{Nickel(II) Ion Amminocomplexing}

Given the known complexing ability of the ammonia molecule for the divalent nickel cation, ${ }^{(20)}$ formation of $\mathrm{Ni}\left(\mathrm{NH}_{3}\right)^{2+}(\mathrm{aq})$ via the $\mathrm{n}=0$ form of Eq. (5) is expected to occur at free ammonia concentrations above 2 millimolal. Incorporation of a second ammonia ligand via

$$
\mathrm{Ni}\left(\mathrm{NH}_{3}\right)^{2+}(\mathrm{aq})+\mathrm{NH}_{3}(\mathrm{aq})=\mathrm{Ni}\left(\mathrm{NH}_{3}\right)_{2}{ }^{2+}(\mathrm{aq})
$$

occurs at free ammonia concentrations above 6.5 millimolal. Since free ammonia concentrations were around 0.6 and 6 millimolal in Runs 2 and 3, respectively, it was prudent to fit up to two ammonia ligands in the sequence of $\mathrm{Ni}(\mathrm{II})$ ion hydrolysis products to form mixed amminohydroxocomplexes.

The enhancement of nickel(II) oxide solubility by formation of ammonia complexes is illustrated by comparing the results of Run 3 (Fig. 5, pH 10.4 ammonium hydroxide) and Run 4 (Fig. 4, pH 10.3 sodium hydroxide). Due to the characteristic hydrolysis behavior of $\mathrm{Ni}(\mathrm{II})$, the dominant soluble $\mathrm{Ni}(\mathrm{II})$ ion species in the low temperature portions of the figures existed as $\mathrm{Ni}(\mathrm{OH})^{+}(\mathrm{aq})$. Therefore, the higher Ni(II) ion solubilities in Run 3 at lower temperatures were fitted by allowing formation of the $\mathrm{Ni}(\mathrm{OH})\left(\mathrm{NH}_{3}\right)^{+}(\mathrm{aq})$ amminohydroxocomplex. The standard free energy change fitted for Eq. $(5)(n=1)$, i.e., $-17.37 \pm 0.61 \mathrm{~kJ} \mathrm{~mol}^{-1}$, compares favorably with that for the $\mathrm{n}=0$ equilibrium, i.e., $-15.48 \mathrm{~kJ} \mathrm{~mol}^{-1}$, indicating that hydrolysis does not significantly affect amminocomplexing. It is noted that $\mathrm{Ni}^{2+}(\mathrm{aq})$ ion concentrations tended to be insignificant 
when the higher levels of ammonia were tested. This behavior allowed formation of the $\mathrm{Ni}\left(\mathrm{NH}_{3}\right)^{2+}(\mathrm{aq})$ and $\mathrm{Ni}\left(\mathrm{NH}_{3}\right)_{2}{ }^{2+}(\mathrm{aq})$ amminocomplexes to be constrained to literature results ${ }^{(20)}$ without loss of generality.

In the high temperature region of Run 3, where hydrolysis provided significant concentrations of $\mathrm{Ni}(\mathrm{OH})_{2}(\mathrm{aq})$, NiO solubilities tended to become relatively insensitive to temperature changes. This behavior contrasted with Run 4, where, at nearly the same $\mathrm{pH}$ level, $\mathrm{NiO}$ solubilities decreased significantly with temperature. Such behavior indicates the presence of an additional amminocomplex, namely $\mathrm{Ni}(\mathrm{OH})_{2}\left(\mathrm{NH}_{3}\right)(\mathrm{aq})$. Although the standard free energy change for the $\mathrm{n}=2$ form of Eq. (5) $\left(-17.65 \pm 5.28 \mathrm{~kJ} \mathrm{~mol}^{-1}\right)$ was found to be nearly the same as that for the $\mathrm{n}=$ 0 and 1 forms, the entropy increase associated with this equilibrium allows $\mathrm{Ni}(\mathrm{OH})_{2}\left(\mathrm{NH}_{3}\right)(\mathrm{aq})$ to remain important at high temperatures (see Fig. 8)

\section{SUMMARY/CONCLUSIONS}

The solubility behavior of nickel(II) oxide (NiO) was investigated in a platinum-lined, flowing autoclave system over the temperature range 21 to $315^{\circ} \mathrm{C}$ using ammonia concentrations in the range 0.06 to 6 millimolal. To separate the effects of $\mathrm{pH}$ and ammonia concentration, additional runs were included using sodium hydroxide. Based on the accumulated database and the subsequent thermodynamic analyses afforded the data, it is concluded that:

1. Depending on temperature, nickel(II) ion solubilities are controlled by one of three nickel(II) oxide dissolution reactions: (a) Below $149^{\circ} \mathrm{C}$ a hydrous nickel oxide phase ( $\beta$ $\mathrm{Ni}(\mathrm{OH})_{2}$, theophrastite) controls the dissolution reaction equilibrium via

$$
\beta-\mathrm{Ni}(\mathrm{OH})_{2}(\mathrm{~s})+2 \mathrm{H}^{+}(\mathrm{aq})=\mathrm{Ni}^{2+}(\mathrm{aq})+2 \mathrm{H}_{2} \mathrm{O}
$$


(b) Above $149^{\circ} \mathrm{C}$, but below $247^{\circ} \mathrm{C}$, anhydrous rhombohedral nickel oxide (NiO, bunsenite) controls the dissolution reaction equilibrium via

$$
\mathrm{NiO}(\mathrm{s}, \text { rhomb })+2 \mathrm{H}^{+}(\mathrm{aq})=\mathrm{Ni}^{2+}(\mathrm{aq})+\mathrm{H}_{2} \mathrm{O} \text {, and }
$$

(c) Above $247^{\circ} \mathrm{C}$ cubic nickel(II) oxide controls the dissolution reaction equilibrium via

$$
\mathrm{NiO}(\mathrm{s}, \text { cubic })+2 \mathrm{H}^{+}(\mathrm{aq})=\mathrm{Ni}^{2+}(\mathrm{aq})+\mathrm{H}_{2} \mathrm{O} \text {. }
$$

Non-linear, least-squares regression analyses of the solubility database allowed free energy changes for all three reactions to be determined with accuracies of $\pm 0.8 \mathrm{~kJ} \mathrm{~mol}^{-1}$ throughout their applicable temperature ranges. The standard free energy changes (i.e., values at room temperature) are found to be in excellent agreement with recent literature results. Inclusion of the rhombohedral-to-cubic transformation of $\mathrm{NiO}$ was found necessary to account for the heat capacity anomaly caused by disordering of magnetic spins on nickel atoms in the NiO lattice.

2. Equilibria for the formation of two nickel(II) ion hydrolysis products were found to be significant, and were characterized by the following reactions:

$$
\mathrm{Ni}^{2+}(\mathrm{aq})+\mathrm{H}_{2} \mathrm{O}=\mathrm{Ni}(\mathrm{OH})^{+}(\mathrm{aq})+\mathrm{H}^{+}(\mathrm{aq})
$$

and

$$
\mathrm{Ni}^{2+}(\mathrm{aq})+2 \mathrm{H}_{2} \mathrm{O}=\mathrm{Ni}(\mathrm{OH})_{2}(\mathrm{aq})+2 \mathrm{H}^{+}(\mathrm{aq})
$$

Free energy changes for the first and second reactions were determined with accuracies of \pm 0.8 and $\pm 3.1 \mathrm{~kJ} \mathrm{~mol}^{-1}$, respectively, throughout the temperature range 21 to $315^{\circ} \mathrm{C}$. Standard free energy changes for the first hydrolysis reaction demonstrated excellent agreement with the room temperature literature. However, the much lower minimum solubilities of $\bar{\beta}-\mathrm{Ni}(\mathrm{OH})_{2}$ at room 
temperature measured in the present program provided standard free energy changes for the second hydrolysis reaction that were more than $20 \mathrm{~kJ} \mathrm{~mol}^{-1}$ greater than reported in the literature. Similar differences were also obtained at elevated temperatures: minimum solubility of $\mathrm{NiO}$ at $300^{\circ} \mathrm{C}(0.5 \mathrm{~nm})$ was lower than reported in the literature $(1.7 \mathrm{~nm}) .{ }^{(1)}$

3. No evidence was found to support inclusion of the third hydrolytic species, $\mathrm{Ni}(\mathrm{OH})_{3}{ }^{-}(\mathrm{aq})$, despite testing at sodium hydroxide concentrations up to 4 millimolal, i.e., $\mathrm{pH}=11.5$.

4. The equilibria for two ammonia complexing reactions were found to enhance nickel(II) ion solubilities at intermediate ammonia levels:

$$
\begin{array}{ll} 
& \mathrm{Ni}(\mathrm{OH})^{+}(\mathrm{aq})+\mathrm{NH}_{3}(\mathrm{aq})=\mathrm{Ni}(\mathrm{OH})\left(\mathrm{NH}_{3}\right)^{+}(\mathrm{aq}) \\
\text { and } & \mathrm{Ni}(\mathrm{OH})_{2}(\mathrm{aq})+\mathrm{NH}_{3}(\mathrm{aq})=\mathrm{Ni}(\mathrm{OH})_{2}\left(\mathrm{NH}_{3}\right)(\mathrm{aq})
\end{array}
$$

The first is a low temperature species and constitutes $35 \%$ of the room temperature solubility of $\beta-\mathrm{Ni}(\mathrm{OH})_{2}$ in $\mathrm{pH} 10 \mathrm{NH}_{4} \mathrm{OH}$; the second is a high temperature species and contributes about $5 \%$ to the solubility of $\mathrm{NiO}$ at $260^{\circ} \mathrm{C}$ in the same $\mathrm{NH}_{4} \mathrm{OH}$ solution. At $\mathrm{pH} 10.3$ and $260^{\circ} \mathrm{C}$, the $\mathrm{Ni}(\mathrm{OH})_{2}\left(\mathrm{NH}_{3}\right)(\mathrm{aq})$ species represents $25 \%$ of the soluble $\mathrm{Ni}(\mathrm{II})$ ions. 


\section{REFERENCES}

1. P. R. Tremaine and J. C. LeBlanc, J. Chem. Thermodyn. 12, 521 (1980)

2. S. E. Ziemniak, M. E. Jones and K. E. S. Combs, J. Solution Chem. 18, 1133 (1989)

3. B. S. Hemingway, Amer. Mineral 75, 781 (1990)

4. D. D. Perrin, J. Chem. Soc. 3644 (1964)

5. JCPDS Powder Diffraction File, International Centre for Diffraction Data, Swarthmore, PA (1999), Sets 1-49

6. D. M. Alexander, D. J. T. Hill and L. R. White, Aust. J. Chem. 24, 1143 (1971)

7. R. E. Mesmer, W. L. Marshall, D. A. Palmer, J. M. Simonson, and H. F. Holmes, J. Solution Chem. 21, 699 (1988)

8. F. H. Sweeton, R. E. Mesmer, and C. F. Baes, J. Solution Chem. 3, 191 (1974)

9. B. F. Hitch and R. E. Mesmer, J. Solution Chem. 5, 667 (1976)

10. W. L. Marshall, R. Slusher, and E. V. Jones, J. Chem. Eng. Data 9, 187 (1964)

11. W. L. Marshall and E. V. Jones, J. Phys. Chem. 20, 4028 (1966)

12. D. D. Wagman, W. H. Evans, V. B. Parker, R. H. Schumm, I. Halow, S. M. Bailey, K. L. Churney, and R. L. Nuttall, J. Phys. Chem. Ref. Data 11, Suppl. 2 (1982)

13. D. L. Marquardt, J. Soc. Ind. Appl. Math. 2, 431 (1963)

14. J. W. Larson, P. Cerutti, H. K. Garber, and L. G. Helper, J. Phys. Chem. 72, 2902 (1968)

15. S. V. Mattigod, D. Rai, A. R. Felmy and L. Rao, J. Solution Chem. 26, 391 (1997)

16. P. Pan and A. B. Campbell, J. Solution Chem. 26, 461 (1997)

17. J. R. Fisher and E. Zen, Amer. J. Sci. 270, 297 (1971)

18. G. T. Bhandage, J. A. K. Tareen and B. Basavalingu, J. Thermal Anal. 32, 1823 (1987)

19. M. Yasuda, K. Fukumoto, Y. Ogata and F. Hine, J. Electrochem. Soc. 135, 2982 (1988)

20. V. P. Vasil'ev and V. A. Borodin, Russ. J. Inorg. Chem. 32, 1099 (1987) 
Table I

\section{Feedwater Compositions}

$\begin{array}{cccc}\underline{\text { Run }} & \begin{array}{c}\text { Ammonia } \\ \text { millimolal }\end{array} & \begin{array}{c}\mathrm{pH} \text { at } \\ 25^{\circ} \mathrm{C}\end{array} & \begin{array}{c}\text { Conductivity } \\ \underline{\mu \mathrm{S} / \mathrm{cm}}\end{array} \\ 1 & 0.074 & 9.35 & 7.8 \\ 1 \mathrm{~A} / \mathrm{B} & 0.074 & 9.35 & 7.2 \\ 2 & 0.710 & 9.90 & 27.5 \\ 2 \mathrm{~A} / \mathrm{B} & 0.737 & 10.05 & 28.3 \\ 3 & 5.70 & 10.40 & 83.8 \\ 3 \mathrm{~A} & 5.70 & 10.53 & 83.7 \\ 4 & 0.19 * & 10.33 & 47.8 \\ 4 \mathrm{~A} & 0.17^{*} & 10.26 & 44.0 \\ 5 & 2.33^{*} & 11.37 & 579 \\ 5 \mathrm{~A} & 2.05^{*} & 11.31 & 510 \\ 6 \mathrm{~A} & 3.91^{*} & 11.58 & 951\end{array}$

* $\mathrm{NaOH}$ millimolality 
Table II

Solubilities of $\mathrm{NiO} / \mathrm{Ni}(\mathrm{OH})_{2}$ in Aqueous Solutions*

\begin{tabular}{|c|c|c|c|c|c|c|c|c|c|}
\hline & $\begin{array}{l}\mathrm{T}(\mathrm{K}) \\
\mathrm{n} 1\end{array}$ & $\mathrm{Ni}^{* *}$ & $\begin{array}{r}T(\mathrm{~K}) \\
\text { In } 2 \\
\end{array}$ & $\mathrm{Ni}^{* *}$ & $\begin{array}{l}\mathrm{T}(\mathrm{K}) \\
\mathrm{n} 3\end{array}$ & $\mathrm{Ni}^{* *}$ & $\begin{array}{r}T(\mathrm{~K}) \\
\mathrm{n} 4 \\
\end{array}$ & $\overline{\mathrm{Ni}}$ & $\begin{array}{r}\mathrm{T}(\mathrm{K}) \\
\mathrm{n} 5 \\
\end{array}$ \\
\hline 106. & 294.8 & 47.7 & 296.5 & 59.6 & 296.5 & 30.0 & 295.4 & 1.5 & 295.9 \\
\hline 182. & 313.7 & 51.1 & 313.2 & 40.9 & 311.5 & 28.4 & 312.0 & 1.6 & 312.0 \\
\hline 257. & 324.3 & 44.3 & 324.8 & 37.5 & 324.8 & 21.3 & 324.3 & 1.7 & 324.8 \\
\hline 232. & 338.2 & 51.1 & 338.7 & 29.0 & 338.7 & 19.9 & 338.7 & 1.7 & 339.8 \\
\hline $325:$ & 350.4 & 49.4 & 350.9 & 22.1 & 351.5 & 12.9 & 350.9 & 1.4 & 350.9 \\
\hline 376. & 362.0 & 49.4 & 363.2 & 12.4 & 366.5 & 13.8 & 352.6 & 1.4 & 365.4 \\
\hline 424. & 382.6 & 47.7 & 380.4 & 11.4 & 380.9 & 11.6 & 365.4 & 1.0 & 380.9 \\
\hline 416. & 395.4 & 47.7 & 394.3 & 10.6 & 394.3 & 9.9 & 380.9 & 0.9 & 394.3 \\
\hline 395. & 408.7 & 42.6 & 408.2 & 10.6 & 408.2 & 9.0 & 394.3 & & \\
\hline 371. & 408.2 & 40.9 & 422.0 & 9.5 & 422.0 & $\begin{array}{l}8.3 \\
8.2\end{array}$ & $\begin{array}{l}410.9 \\
422.0\end{array}$ & & \\
\hline \multicolumn{2}{|c|}{ Run $1 \mathrm{~A}$} & \multicolumn{2}{|c|}{ Run 1B } & \multicolumn{2}{|c|}{ Run 2A } & \multicolumn{2}{|c|}{ Run 2B } & \multicolumn{2}{|c|}{ Run $3 \mathrm{~A}$} \\
\hline 436. & 422.0 & 365. & 422.0 & & & & & & \\
\hline 368. & 435.9 & 286. & 435.9 & (112) & 435.9 & 35.6 & 435.9 & 9.4 & 435.9 \\
\hline 276. & 449.8 & 245. & 449.8 & 33.0 & 449.8 & 32.5 & 449.8 & 8.7 & 449.8 \\
\hline 216. & 463.2 & 186. & 463.7 & $(47.2)$ & 463.7 & 27.6 & 463.7 & 8.0 & 463.2 \\
\hline 181. & 477.6 & 143. & 477.6 & 23.0 & 477.6 & 22.5 & 477.6 & 7.0 & 477.6 \\
\hline 124. & 491.5 & 101. & 491.5 & $(35.3)$ & 491.5 & 15.2 & 491.5 & 7.2 & 491.5 \\
\hline 86.9 & 504.8 & 64.6 & 504.8 & $(21.5)$ & 505.4 & 14.0 & 505.4 & 8.0 & 504.8 \\
\hline 46.8 & 518.7 & 56.7 & 519.3 & 17.4 & 519.3 & 9.2 & 519.3 & 8.2 & 518.7 \\
\hline 30.7 & 533.2 & 40.7 & 533.7 & 11.4 & 533.7 & 10.0 & 533.2 & 7.5 & 533.2 \\
\hline 36.8 & 547.0 & 32.7 & 546.5 & 11.1 & 546.5 & 11.6 & 547.6 & 6.6 & 547.0 \\
\hline 28.1 & 560.9 & 31.2 & 560.9 & 9.4 & 560.9 & 11.1 & 560.4 & 6.8 & 560.9 \\
\hline 22.7 & 575.4 & 26.9 & 574.3 & 10.4 & 574.8 & 10.0 & 574.8 & 6.8 & 574.8 \\
\hline 22.7 & 588.7 & $(34.1)$ & 588.7 & 9.5 & 588.7 & 11.6 & 588.7 & 8.9 & 588.7 \\
\hline
\end{tabular}

* All concentrations determined by GFAA. Parentheses denote suspect data exhibiting hysteresis that were excluded from least-squares analysis.

** Units: $10^{-9}$ mol-kg water ${ }^{-1}$. 
Table III

Measured Solubilities of Bunsenite $(\mathrm{NiO})^{*}$

\begin{tabular}{|c|c|c|c|c|c|c|c|}
\hline \multicolumn{2}{|c|}{$\begin{array}{c}\text { Ni** } \\
\text { Run 3B }\end{array}$} & \multicolumn{2}{c|}{$\begin{array}{c}\text { Ni** } \\
\text { Run 4A }\end{array}$} & \multicolumn{2}{c|}{$\begin{array}{c}\text { Ni** } \\
\text { Run } 5 \mathrm{~A}\end{array}$} & \multicolumn{2}{c|}{$\begin{array}{c}\text { Ni** } \\
\text { Run 6A }\end{array}$} \\
\hline 10.3 & 435.9 & 6.73 & 435.9 & 0.65 & 435.9 & & \\
9.47 & 449.8 & 5.25 & 450.9 & 0.49 & 449.8 & & \\
8.94 & 463.2 & 4.45 & 463.7 & 0.46 & 463.7 & & \\
7.89 & 477.6 & 3.49 & 478.7 & 0.49 & 477.6 & 0.63 & 477.6 \\
8.35 & 491.5 & 3.00 & 491.5 & 0.49 & 491.5 & 0.65 & 491.5 \\
7.19 & 504.8 & 2.35 & 505.4 & 0.53 & 505.4 & 0.56 & 505.4 \\
6.32 & 518.7 & 1.96 & 519.3 & 0.58 & 519.3 & 0.60 & 519.3 \\
6.35 & 533.2 & 2.15 & 533.2 & 0.61 & 533.2 & 0.44 & 533.7 \\
5.23 & 547.0 & 1.64 & 547.0 & 0.63 & 547.0 & 0.63 & 547.6 \\
5.52 & 560.9 & 1.26 & 560.9 & 0.58 & 560.9 & 0.70 & 560.9 \\
6.61 & 574.8 & 1.16 & 574.8 & 0.68 & 575.4 & 0.82 & 574.8 \\
6.29 & 588.7 & 1.31 & 588.7 & 0.82 & 588.7 & 1.06 & 588.7 \\
\hline
\end{tabular}

* All concentrations determined by ICP-MS. Duplicate sample analyses from Run 3A (GFAA), as represented by Run 3B (ICP-MS), were averaged prior to leastsquares analysis.

**Units $=10^{-9}$ mol-kg water $^{-1}$ 
Page 29

Table IV

Ionization Behavior of Selected Compounds

\begin{tabular}{ccccccc}
$\begin{array}{c}\text { Compound } \\
\text { Undergoing } \\
\text { Ionization }\end{array}$ & $\mathrm{b}_{1}$ & $\mathrm{~b}_{2}$ & $\mathrm{~b}_{3}$ & $\mathrm{~b}_{4}$ & $\mathrm{~b}_{5}$ & Reference Cited \\
\hline $\mathrm{H}_{2} \mathrm{O}$ & $31,286.0$ & -606.522 & 94.9734 & -0.097611 & $-2,170,870$ & $\begin{array}{l}\text { Sweeton, Mesmer and } \\
\text { Baes [8] }\end{array}$ \\
$\mathrm{NH}_{4} \mathrm{OH}$ & $27,496.7$ & -513.761 & 81.2824 & -0.0905795 & $-1,717,720$ & Hitch and Mesmer [9]
\end{tabular}


Table V

Thermodynamic Parameters Fitted for the Calculation of

Nickel Oxide Solubility Behavior in Sodium and Ammonium Hydroxide Solutions*

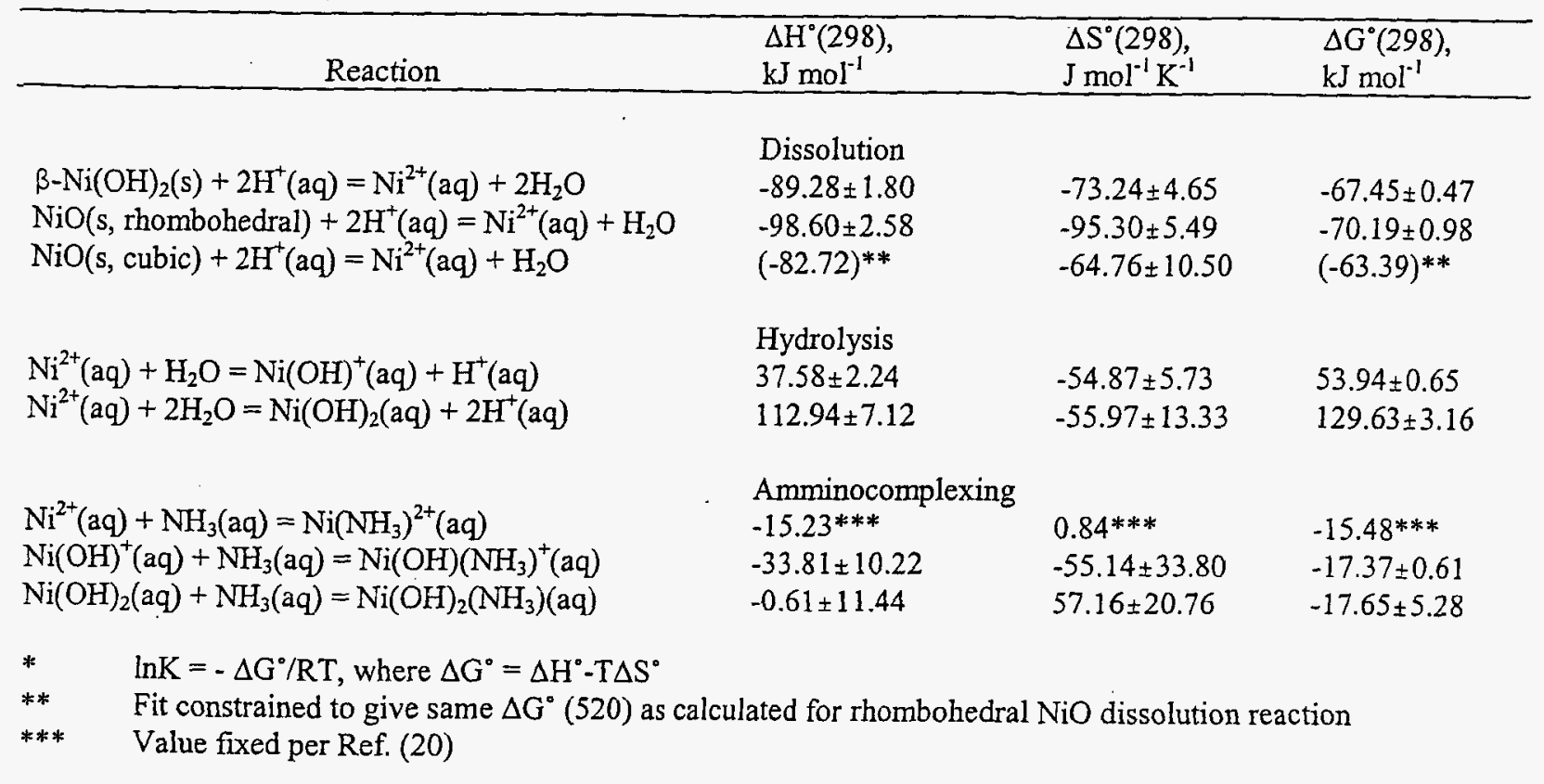




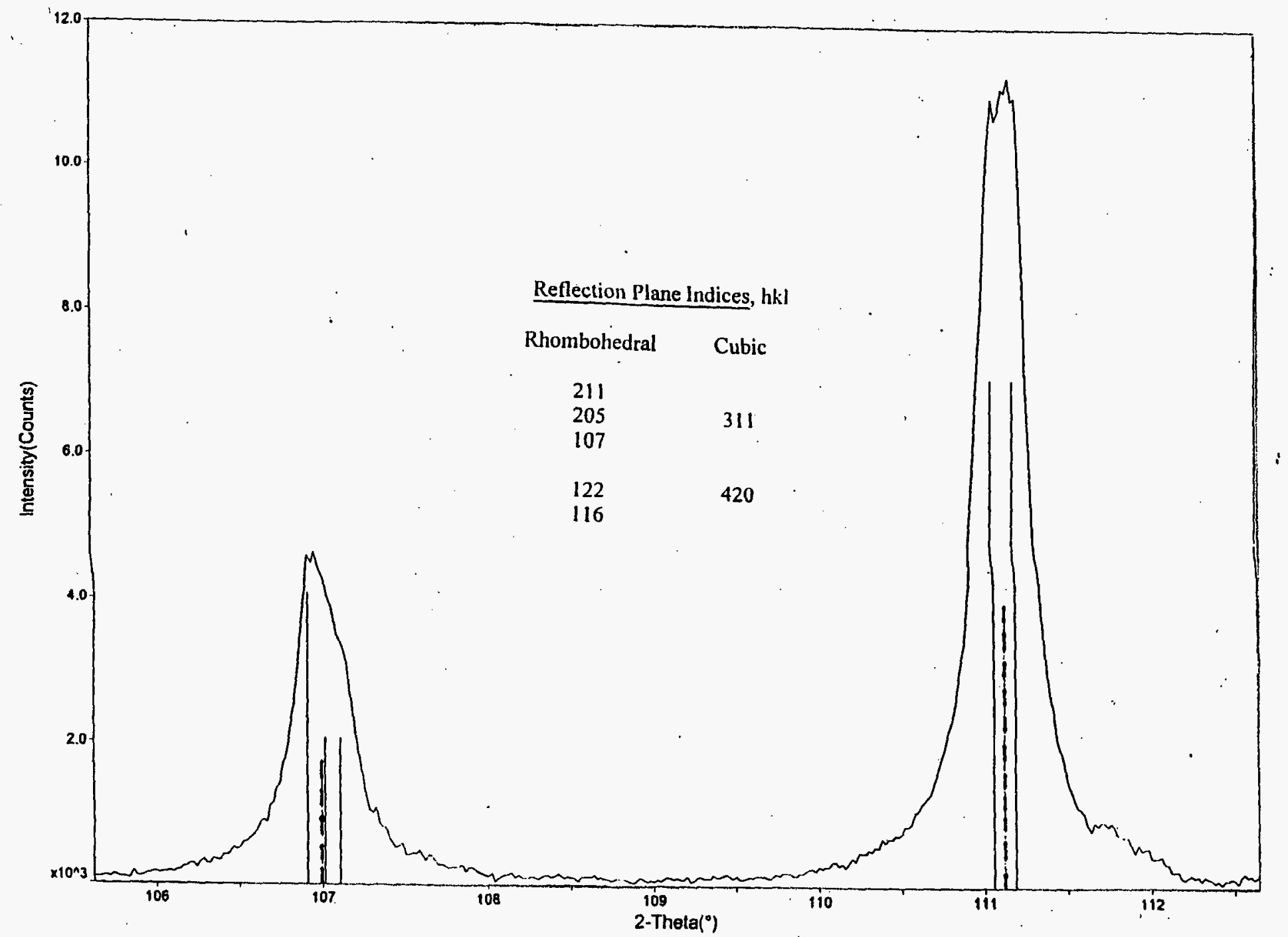

Fig. 1. Comparison of higher angle X-ray diffraction peaks for coarsened $\mathrm{NiO}$ with lines for rhombohedral ( - ) and cubic ( ----)
nickel(II) oxide; copper $\mathrm{K}_{\alpha}$ radiation). w nickel(II) oxide; copper $\mathrm{K}_{\alpha}$ radiation). 


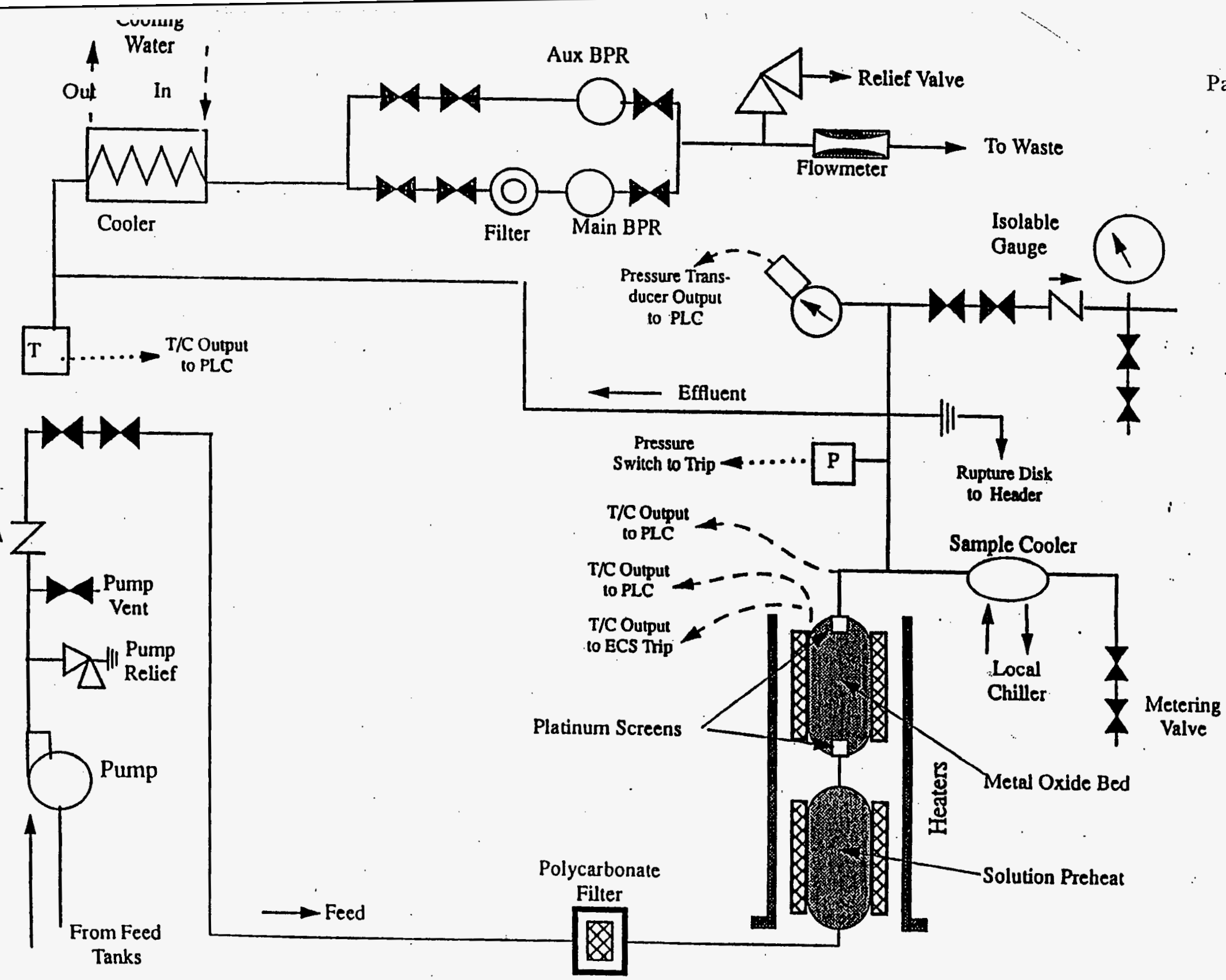

Fig. 2. Schematic of flowing autoclave system used in nickel oxide solubility investigation 


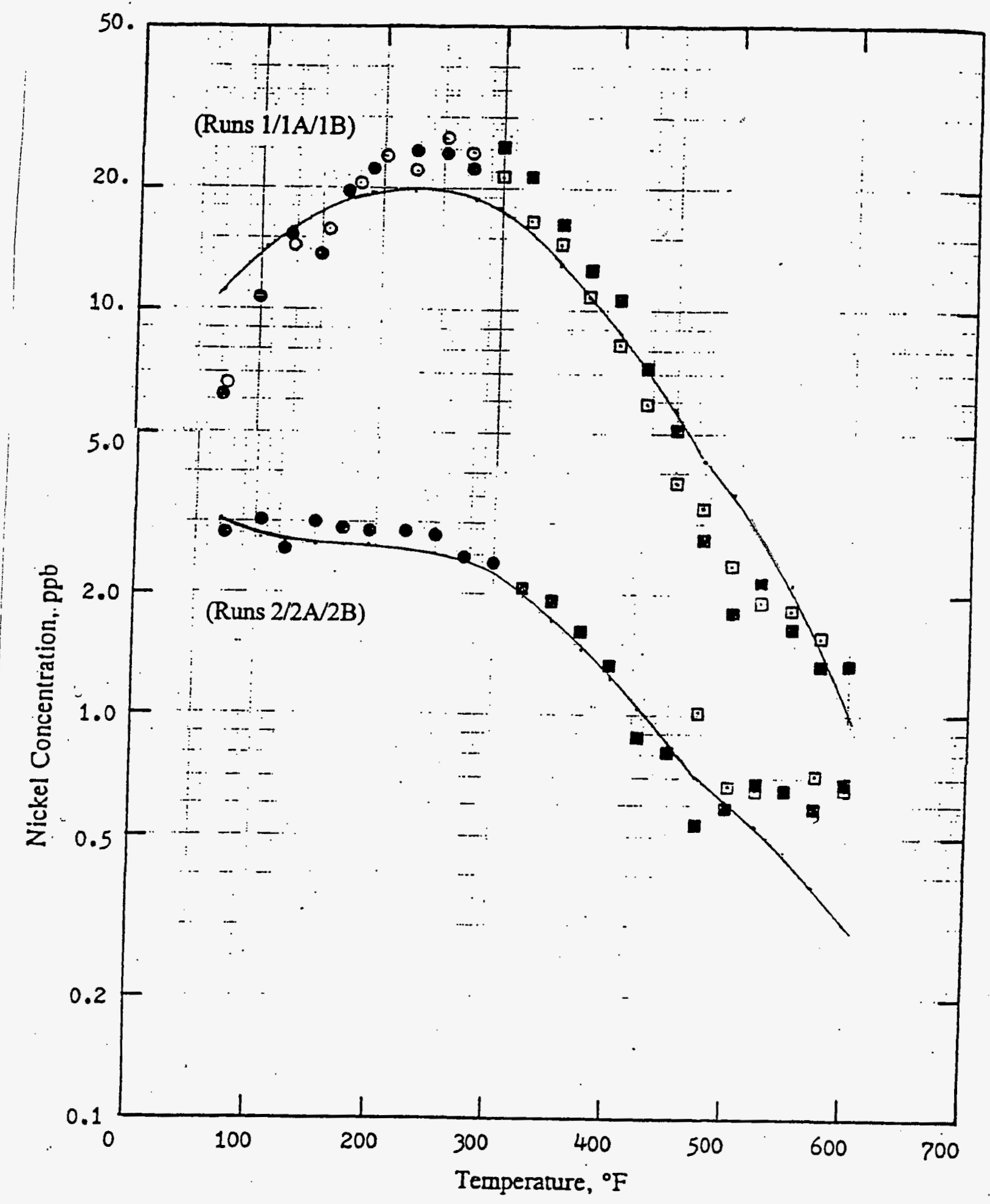

Fig. 3. Comparison of measured and predicted solubilities of (hydrous) nickel(II) oxide in aqueous ammonium hydroxide: Runs $1 / 1 \mathrm{~A} / 1 \mathrm{~B}, \mathrm{NH}_{3} \approx 0.07 \mathrm{~mm}$; Runs $2 / 2 \mathrm{~A} / 2 \mathrm{~B}, \mathrm{NH}_{3}$ $\approx 0.7 \mathrm{~mm}$. 


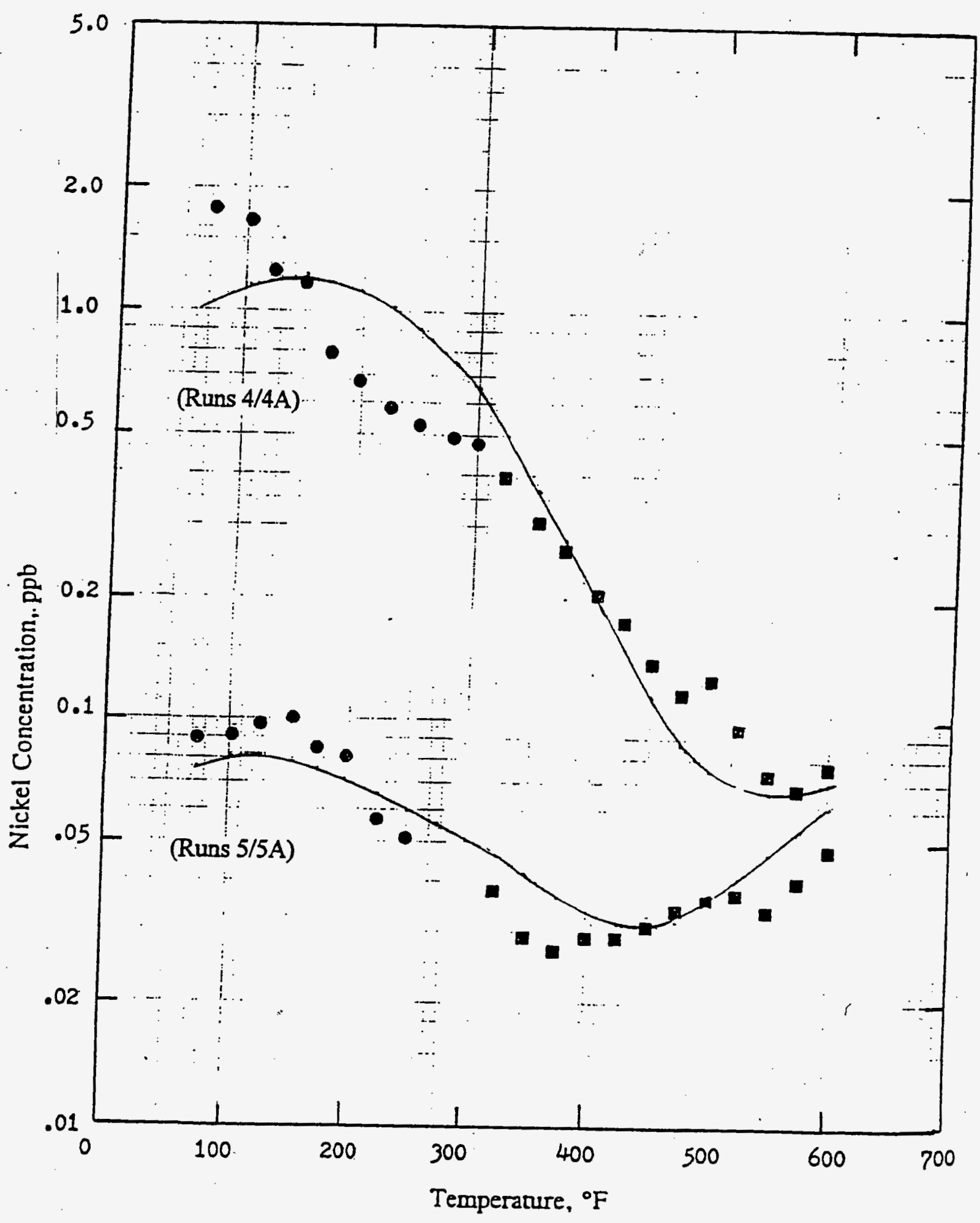

Fig. 4. Comparison of measured and predicted solubilities of (hydrous) nickel(II) oxide in. aqueous sodium hydroxide: Runs $4 / 4 \mathrm{~A}, \mathrm{NaOH} \approx 0.19 \mathrm{~mm}$; Runs $5 / 5 \mathrm{~A}, \mathrm{NaOH} \approx 2 \mathrm{~mm}$. 


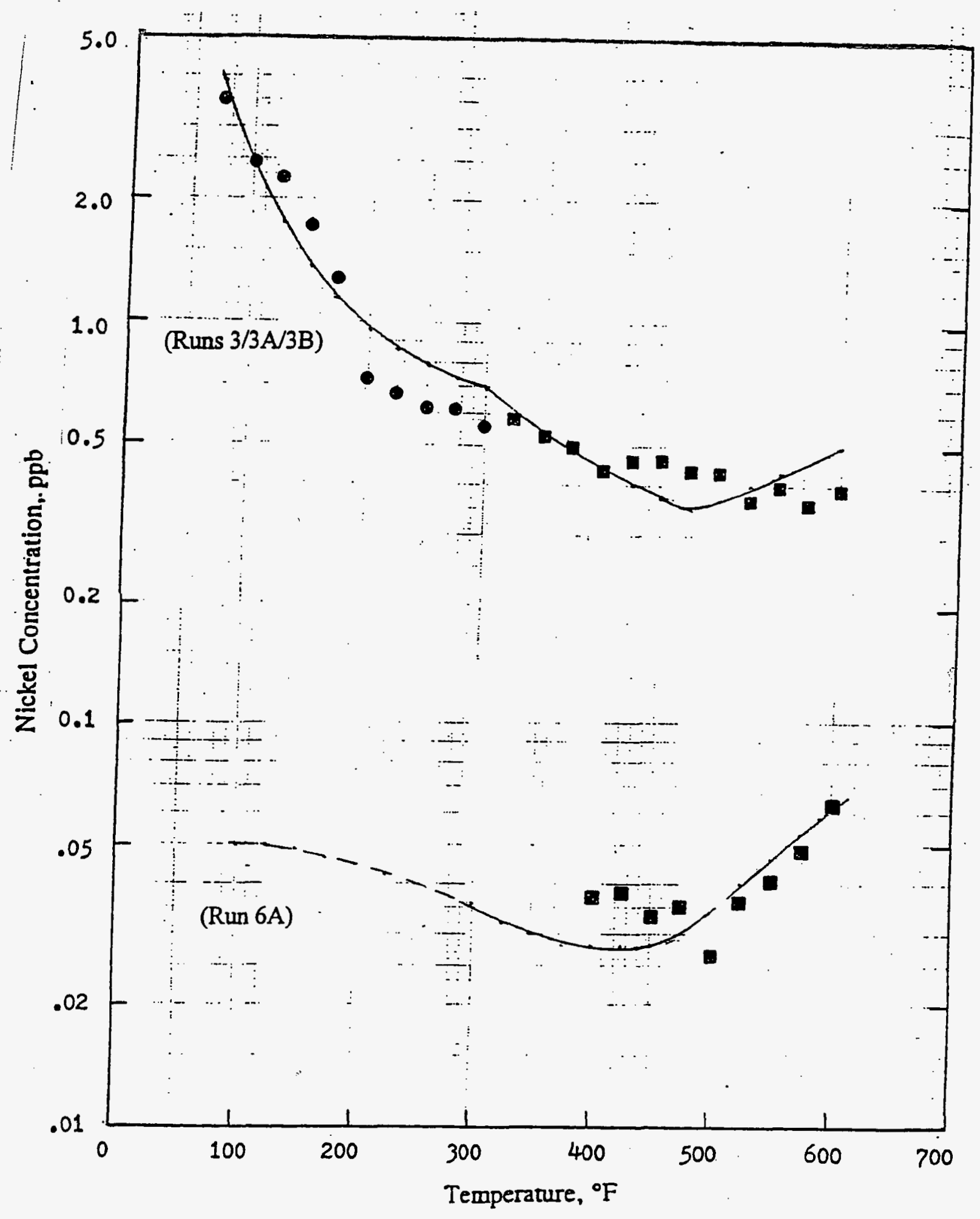

Fig. 5. Comparison of measured and predicted solubilities of (hydrous) nickel(II) oxide in alkaline solutions: Runs $3 / 3 \mathrm{~A} / 3 \mathrm{~B}, \mathrm{NH}_{3} \approx 7 \mathrm{~mm} ; \mathrm{Run} 6, \mathrm{NaOH} \approx 4 \mathrm{~mm}$. 


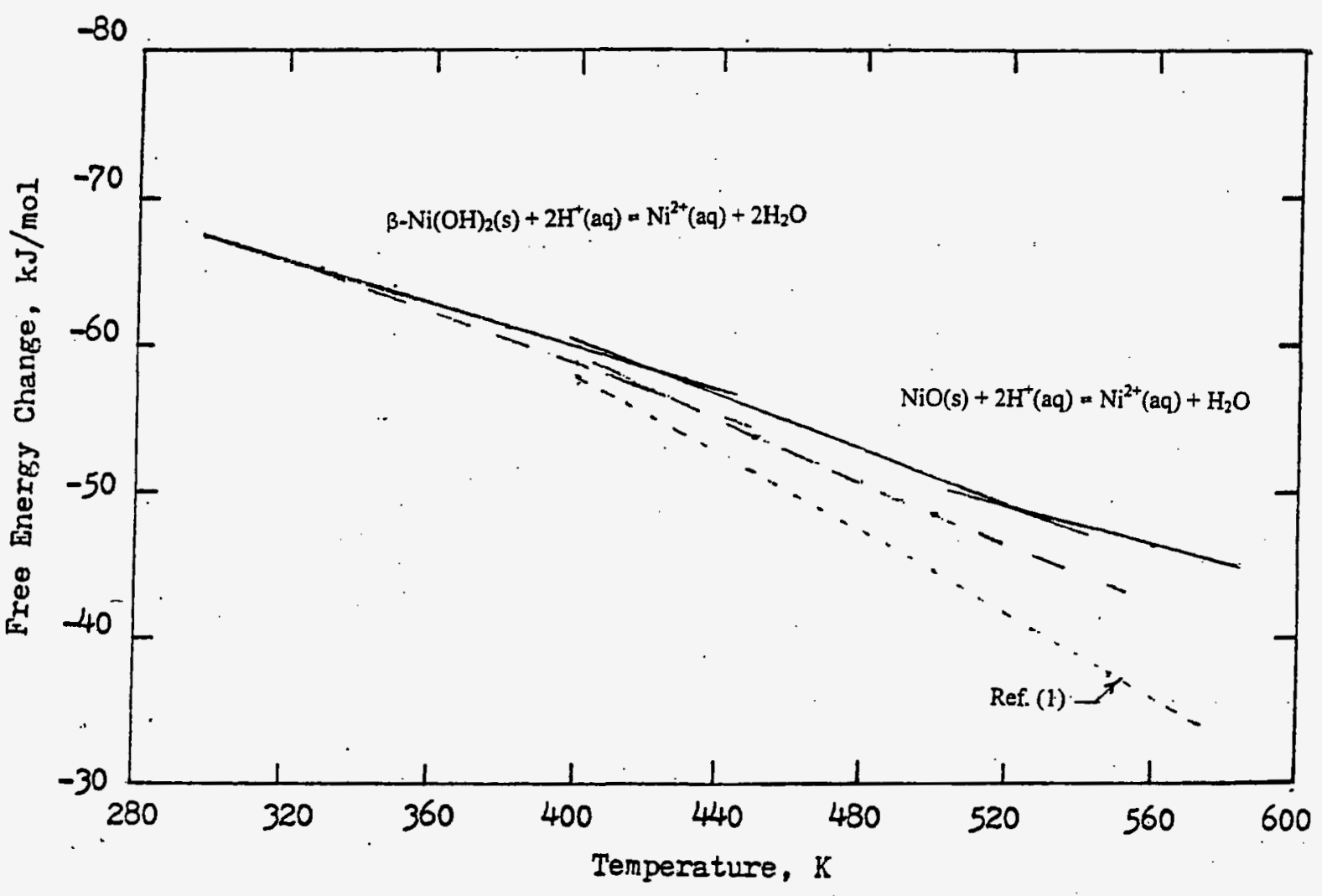

Fig.6. Free energy changes for theophrastite/bunsenite dissolution reactions in aqueous solutions. Eqs. $(14,15)$ predictions shown as dashed lines. 


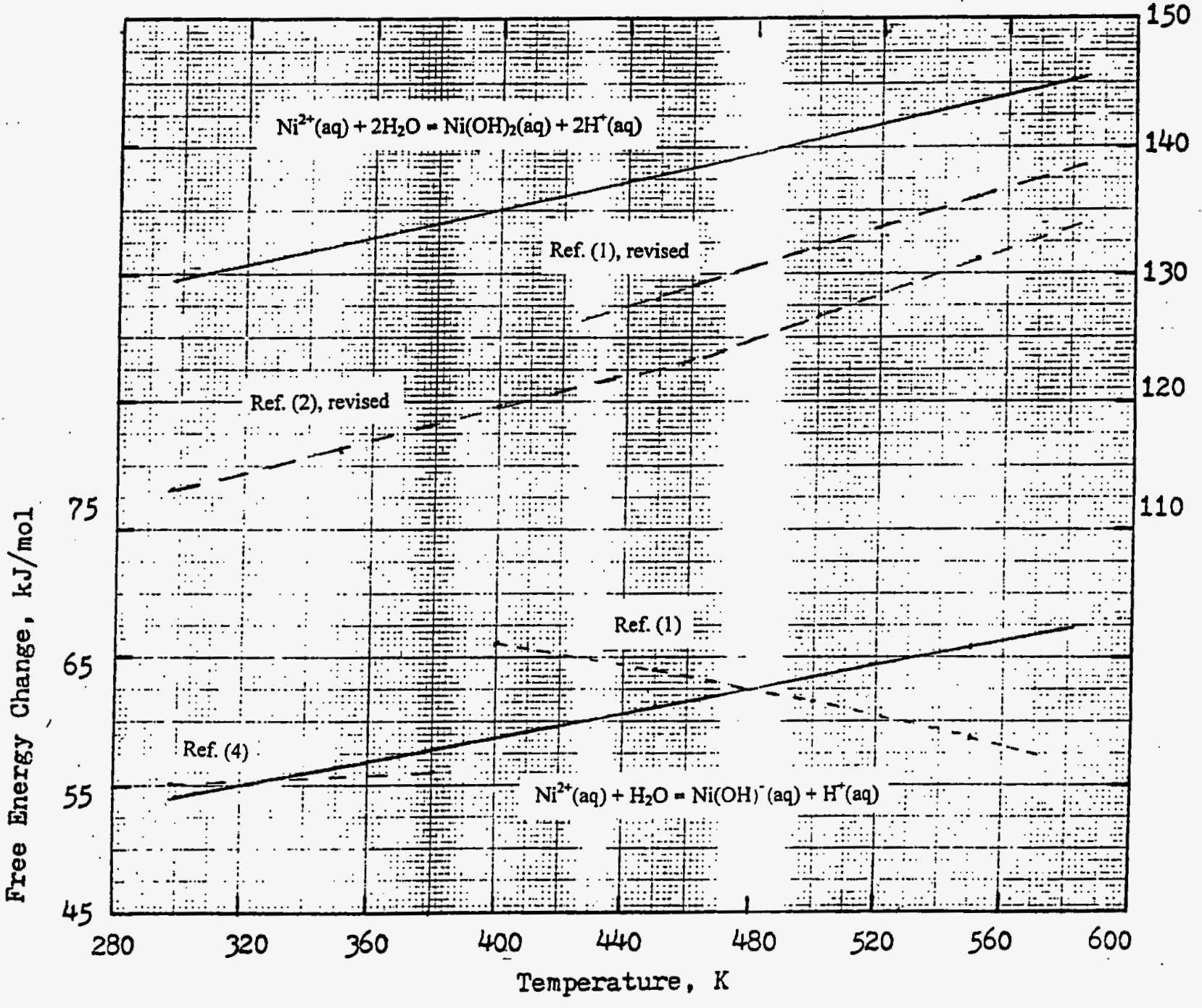

Fig. 7. Free energy changes for first two hydrolysis reactions of the Ni(II) ion. 


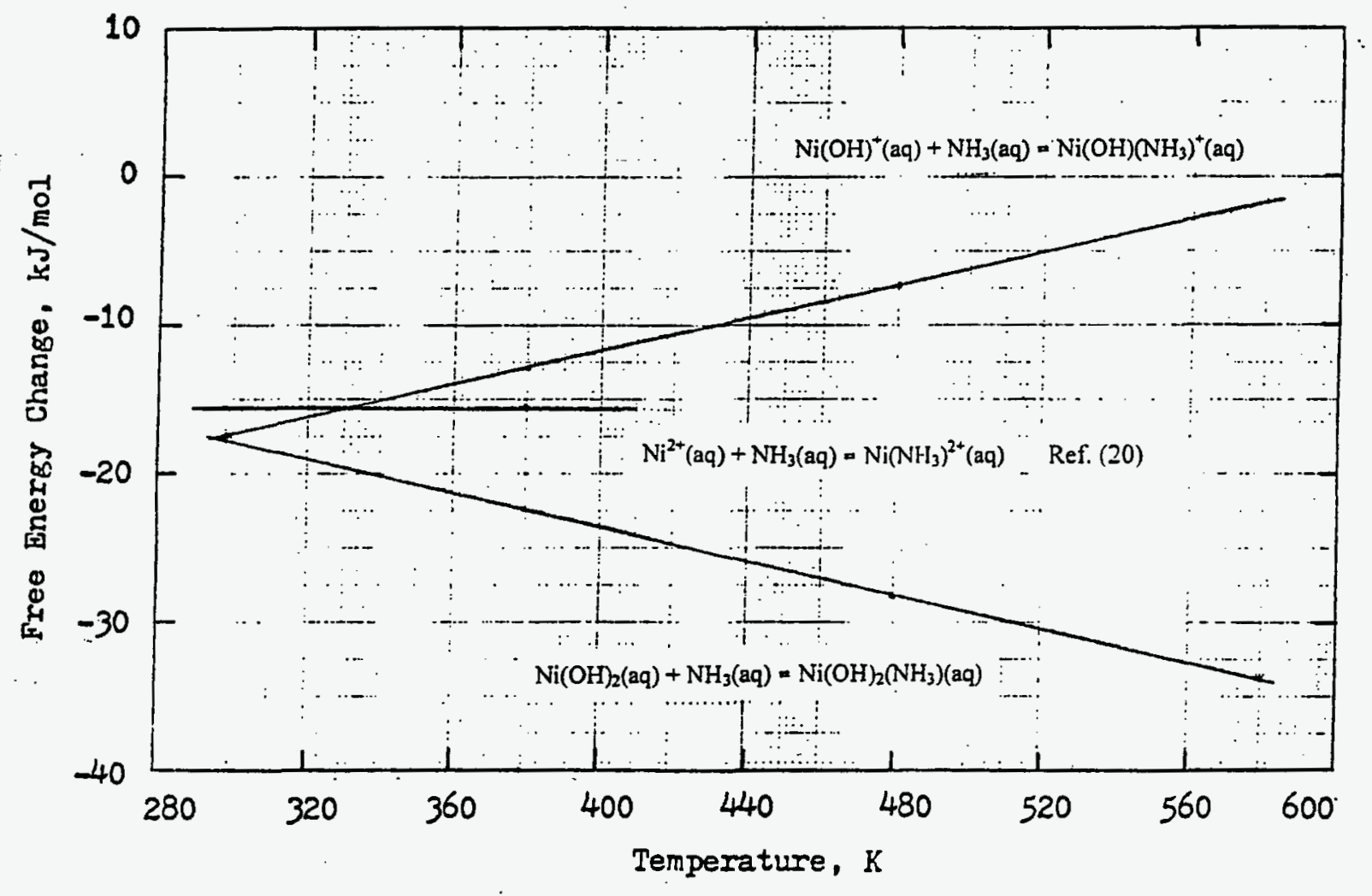

Fig. 8. Free energy changes for amminocomplexing reactions of $\mathrm{Ni}$ (II) ion hydrolysis products. 